Atmos. Chem. Phys. Discuss., https://doi.org/10.5194/acp-2018-36

Manuscript under review for journal Atmos. Chem. Phys.

Discussion started: 7 March 2018

(c) Author(s) 2018. CC BY 4.0 License.

(c) (1)

\title{
$1 \quad$ VOCs emission profiles from rural cooking and heating 2 in Guanzhong Plain, China and its potential effect on regional $\mathrm{O}_{3}$ and $\mathrm{SOA}$ formation
}

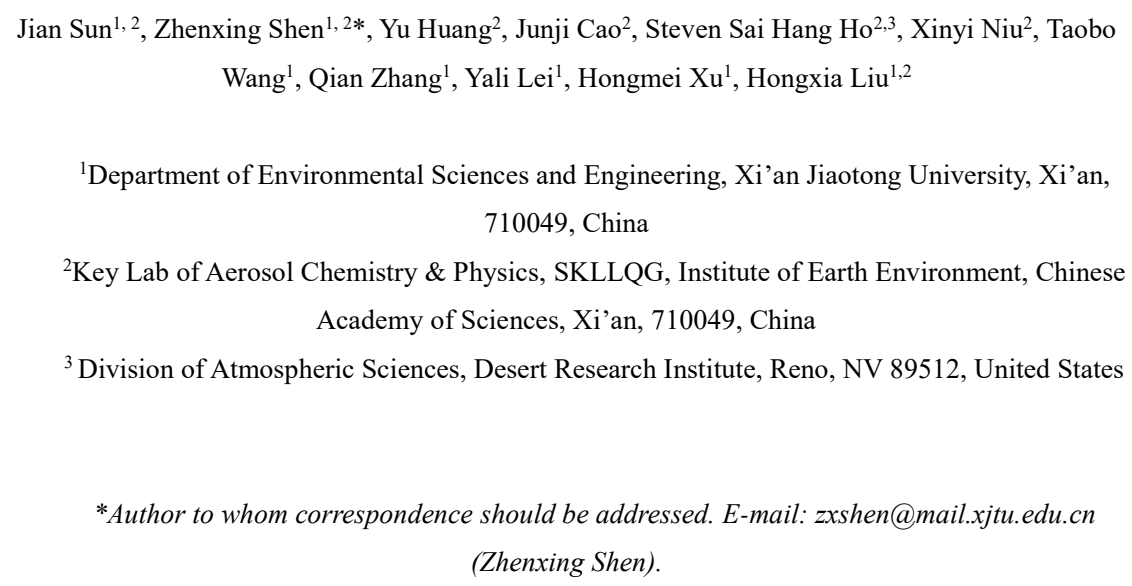


Atmos. Chem. Phys. Discuss., https://doi.org/10.5194/acp-2018-36

Manuscript under review for journal Atmos. Chem. Phys.

Discussion started: 7 March 2018

(c) Author(s) 2018. CC BY 4.0 License.

(c) (1)

20

21

22

23

24

25

26

27

28

\begin{abstract}
Solid fuels (i.e., biomass fuel and coal) burning for cooking and heating emit large amounts of pollutants into atmosphere including particulate matter (PM) and volatile organic compounds (VOCs). In this study, VOCs were directly collected in chimneys of residential cooking and heating stoves in Guanzhong Plain using adsorbent tube approach followed by thermal desorption-gas chromatography/mass spectrometry (TD-GC/MS) analysis. Emission factors (EFs) of targeted VOCs varied from $47.2 \pm 19.4$ to $3121.3 \pm 1592.4 \mathrm{mg} \mathrm{kg}^{-1}$ which had a descending order of biomass straw > woody fuel $\gg$ coal fuels. A remarkable finding is that semi-gasifier could not suppress the VOCs emission even though a high efficiency in reduction of PM was demonstrated. In addition, high values of coefficients of divergence (CD) (most >0.5) support that there were large variations on the VOC profiles with different fuels and stoves. Ozone formation potential (OFP) of VOCs from solid fuel burning ranged from 50.3 to $5914.8 \mathrm{mg} \mathrm{kg}^{-1}$, contributing $20 \%$ of ozone formation in Guanzhong atmosphere. The values were much larger than the contribution from PM of 6.7\%. However, much lower secondary organic aerosol formation potentials (SOAP) $\left(0.5-45.6 \mathrm{mg} \mathrm{kg}^{-1}\right)$ of VOCs emitted from solid fuel burning were estimated. The values were two orders of magnitude lower than OFP and only accounted for $0.23 \%$ of the SOA in Guanzhong in 2013. The results of this study demonstrated that the VOCs emission from solid fuel burning had a strong impact to the ozone pollution in Guanzhong Plain.
\end{abstract}


Atmos. Chem. Phys. Discuss., https://doi.org/10.5194/acp-2018-36

Manuscript under review for journal Atmos. Chem. Phys.

\section{Introduction}

Solid fuels (mainly biomass and coal) are extensively used for daily cooking and heating in developing countries, particularly occurred in rural regions (Shen et al., 2013). Biomass burning is the largest contributor of fine carbonaceous particles and second largest source of trace gases in the global atmosphere (Akagi et al., 2011; Andreae et al., 2001). Over $60 \%$ of households adopt traditional biomass resources as major fuels (Hou et al., 2017). Additional contribution from coal burning should not be underestimated as well. However, because of relatively low efficiencies of burning with residential stoves, large quantities of incomplete combustion byproducts such as fine particulate matter (PM) and volatile organic compounds (VOCs) are emitted (Adkins et al., 2010; Zhang and Smith, 2007).

Chemical profiles of PM emitted from residential burning of solid fuel have been widely studied (Bonjour et al., 2013; Lei et al., 2011; Winijkul and Bond, 2016). Studies on trace gases including VOCs are relatively rare even though their influences on atmospheric pollution can be comparable to PM (Lee et al., 2005). VOCs participate in formations of tropospheric ozone $\left(\mathrm{O}_{3}\right)$ and other atmospheric oxidants, as well as secondary organic aerosols (SOA) in particulate phase (Duan et al., 2008; Liu et al., 2008). Primary-emitted VOCs towards with the resulting photochemical oxidants and fine particles can lead severe regional air pollutions and contribute to climate change (Langmann et al., 2009; Yuan et al., 2010). With discrepancies of burning conditions, fuels and apparatus (i.e., fuel and stove types), emission factors (EFs) of VOCs are highly valuable among different regions or even close areas (Iinuma et al., 2010; Li et al., 2009; Reid et al., 2005).

Guanzhong Plain, with an area of $\sim 36,000 \mathrm{~km}^{2}$ and a population size of 23.92 million, is surrounded by Qinling Mountains to the south and the Loess Plateau to the north (Figure S1), where atmospheric dispersion is typically weak due to its unique features of topography (Niu et al., 2016). Hou et al. (2017) reported that solid fuel burning has a dependency level of $>80 \%$ energy consumption for Guanzhong Plain (Hou et al., 2017), and plays a crucial role in haze and episode events in wintertime (Cao et al., 2005; Shen et al., 2009; Zhang et al., 2015). PM emitted from rural cooking and heating activities to the region has been well studied. In this paper, we particularly focus on the VOCs emissions from solid fuel burning in Guanzhong Plain. A comprehensive measurement campaign was conducted in its rural area. The objectives of this study are to determine the EFs of VOCs from rural solid fuel burning activities and their contributions to regional $\mathrm{O}_{3}$ and $\mathrm{SOA}$ formations.

\section{Methodology}

\subsection{Sample collection}

VOCs samples were collected at three typical agricultural villages in rural Guanzhong Plain (Fig. S1). The village in Weinan city (V1) had the highest number of residents ( 2000). Apple tree is the dominated crop breed and its wood branches and logs are often used as fuels in traditional stove, which is named as "Heated Kang" (Fig. S2a). At the village in Xianyang city (V2), residents mainly use coal and wood branches for household heating and cooking, respectively. The village in Baoji city (V3) is located at a core grain-producing area in Guanzhong Plain, where maize and wheat residues were used for both heating and cooking in Heated Kang. Detailed information on the solid fuels and stoves are summarized in Table S1. Three types of stoves were applied, including Heated Kang, traditional coal 
Atmos. Chem. Phys. Discuss., https://doi.org/10.5194/acp-2018-36

heating stove (Fig S2b) and semi-gasifier stove (Fig. S2c). The characteristics of Heated Kang have been described in Sun et al. (2017). Traditional coal heating stove was a commonly used heating device with simple ion structure in Northern China. Fuels (e.g. anthracite) was combusted in the furnace chamber and heat was transferred with low efficiencies by heat conduction or thermal radiation. Semi-gasifier stove was based on a core technology called "secondary air supply" which could efficiently enhance the combustion efficiency and also reduce PM EFs (Sun et al., 2017). Totally 8 types of solid fuels were selected in this study, namely firewood, branch, maize straw, wheat straw, corncob, anthracite, honey-comb and bitumite. These solid fuels were representative in rural Guanzhong.

VOCs samples in this study were all collected in field experiments. The sampling platform was set at rooftop and beside the chimney of each stove. A self-made dilution system with dilution rate from 5- to 50-fold was employed to collect the smoke emitted from solid fuel burning. More information about the dilution system could refer our previous studies (Sun et al., 2017). Experiments were conducted during real scenarios that residents used the stoves and solid fuels as their daily life. For cooking use, fuels were weighted before and after burning to clear the net fuel consumption, and the sampling period covered the whole cooking process. For heating activities, we weighted the fuels every time they added into the stove and sampling period covered several circles due to different duration of fuels and stoves. Certain number of parallel diluted smoke channels were set for not only VOCs but also other monitors such as $\mathrm{PM}_{2.5}$. For VOCs sampling, air-stream of diluted smoke was drawn into a $1 / 4$ " o.d. stainless steel multi-bed adsorbent tube filled with Tenax-TA, Carbograph I TD and Carboxen 1003 (Markes International Ltd., Llantrisant, U.K.) using a low-flow module pump (ACTI-VOC, Markes International Ltd.) at a flow rate of $50 \mathrm{~mL} \mathrm{~min}^{-1}$ for 30-60 min due to different VOCs concentrations. A Teflon filter assembly (47mm, Whatman, Clifton, NJ, USA) and a home-made ozone scrubber, manufactured by a $1 \mathrm{~m}$ long and $1 / 4$ " o.d. saturated potassium iodide (KI) coated copper tube, were installed in the air upstream to remove any influences from $\mathrm{PM}$ and $\mathrm{O}_{3}$, respectively. The sorbent tubes were pre-cleaned in a thermal conditioner (TC-20, Markes International Ltd.) at $330^{\circ} \mathrm{C}$ for $20 \mathrm{~min}$. All pre-conditioned and sampled tubes were capped and shipped at $0{ }^{\circ} \mathrm{C}$. Insignificant breakthrough $(<5 \%)$ was observed either in field or laboratory demonstration under this sampling flow and volume (Ho et al., 2017). Two sorbent tube samples were thus collected in each test and one field blank was collected on each sampling campaign.

\subsection{Chemical analysis}

A total 27 valid sorbent tube samples were collected. The samples were analyzed using a thermal desorption (TD) unit (Series 2 UNITY-xr system, Markes International Ltd.) coupled with a gas chromatograph/mass spectrometric detector (GC/MSD, Models 7890A/5977B, Agilent, Santa Clara, CA, USA). A tube was connected into the TD unit at room temperature $\left(\sim 25^{\circ} \mathrm{C}\right)$ and purged with ultra-high purity (UHP) helium (He) gas at a flow rate of $40 \mathrm{~mL} \mathrm{~min}{ }^{-1}$ for $10 \mathrm{~s}$ to eliminate air and oxygen intrusion. For the primary desorption stage, the analytes were desorbed at $330{ }^{\circ} \mathrm{C}$ for $5 \mathrm{~min}$ and refocused onto a cryogenic-trap (U-T1703P-2S, Markes International Ltd.) to capture high volatility target compounds at $-15^{\circ} \mathrm{C}$. For the secondary desorption stage, the trap was dry-purged for $10 \mathrm{~s}$ and rapidly heated from $-15{ }^{\circ} \mathrm{C}$ to $320^{\circ} \mathrm{C}$ and maintained for $5 \mathrm{~min}$. The analytes were passed via a heated 
Atmos. Chem. Phys. Discuss., https://doi.org/10.5194/acp-2018-36

transfer line at $160{ }^{\circ} \mathrm{C}$, and re-refocused onto a cold GC capillary column head (Rtx®)-1, $105 \mathrm{~m} \times 0.25 \mathrm{~mm} \times 1 \mu \mathrm{m}$ film thickness, Restek Corporation, Bellefonte, PA, USA) at $-45^{\circ} \mathrm{C}$ with an aid of liquid nitrogen $\left(\mathrm{N}_{2}\right)$ in $\mathrm{GC}$ oven. Once the second desorption is completed, the oven temperature program started at an initial temperature of $-45^{\circ} \mathrm{C}$ for $4 \mathrm{~min}$, ramped to $230{ }^{\circ} \mathrm{C}$ at a rate of $6{ }^{\circ} \mathrm{C} \mathrm{min}{ }^{-1}$, and maintained at $230{ }^{\circ} \mathrm{C}$ for $5 \mathrm{~min}$. The constant flow rate of $\mathrm{He}$ carrier gas was $1.0 \mathrm{~mL} \mathrm{~min}-1$ throughout the GC analysis. The MSD was operated in selective ion monitoring (SIM) mode at $230{ }^{\circ} \mathrm{C}$ and $70 \mathrm{eV}$ for electron ionization. Identification was achieved by comparing the mass spectra and retention times of the chromatographic peaks with those authentic standards. Certified PAMS standard mixtures (Restek Corporation) were used in calibrations. A multi-point calibration curve was established to quantify each of the target compounds with linearity $>0.999$. The minimum detection limits (MDL) for 57 target analytes were in the range of 0.003-0.808 ppbv with a sampling volume of 3 L. The measurement precisions for the analysis of eight replicates of standard samples at 2 ppbv were $\leq 5 \%$. Duplicate samples were collected and the reproducibility was better than $95 \%$. Detailed sampling and analytical method was shown in Ho et al. (2017).

\subsection{Emission factors calculation}

EFs were calculated based on fuel weight consumption $\left(\mathrm{mg} \mathrm{kg}^{-1}\right)$ as equation of

$$
E F=\frac{m_{\text {tube }} \times D R \times t_{\text {sample }} \times V_{\text {stk }} \times D}{Q_{\text {tube }} \times m_{\text {fuel }}}
$$

where $m_{\text {tube }}$ is the mass of VOC in the adsorbent tube (in $\mathrm{mg}$ ), $D R$ is the dilution ratio, $t_{\text {sample }}$ is sampling duration (s), $V_{\text {Stk }}$ is stack flow velocity $\left(\mathrm{m} \mathrm{s}^{-1}\right)$, and $D$ is stack cross section area of chimney $\left(\mathrm{m}^{2}\right), Q_{t u b e}$ is sampling volume through the adsorbent tube $\left(\mathrm{m}^{3}\right)$, and $m_{\text {fuel }}$ is fuel consumption $(\mathrm{kg})$.

\section{Results \& Discussion}

\subsection{Emission factors}

EFs of eight organic classes of VOCs for the examined solid fuels were summarized in Table 1. On average, the EFs for biomass fuels (1122.2 $\left.\pm 178.9-3121.3 \pm 1592.4 \mathrm{mg} \mathrm{kg}^{-1}\right)$ were higher than those for coal fuels $\left(47.2 \pm 19.4-996.8 \pm 476.9 \mathrm{mg} \mathrm{kg}^{-1}\right)(\mathrm{p}<0.05)$. Among the biomass fuels, the values of EFs had a descending order of corncob $>$ branch $>$ firewood $>$ maize straw $>$ wheat straw. Our measured EFs are within the ranges reported for the biomass fuels shown in other relevant studies ( $\mathrm{Li}$ et al., 2009; Wang et al., 2014). Our observations support that stoves and burning modes are dominating factors affected the EFs (Li et al., 2009). First, straws emitted more halogen-containing VOCs (93.2 \pm 23.2 and $\left.311.2 \pm 125.3 \mathrm{mg} \mathrm{kg}^{-1}\right)$ than woody fuels (i.e., firewood and branch) $\left(45.3 \pm 5.3\right.$ and $\left.40.4 \pm 12.1 \mathrm{mg} \mathrm{kg}^{-1}\right)$ with Heated Kang $(\mathrm{p}<0.05)$. It can be ascribed with the features of biomass straws, which had higher chloride contents than woody plants (Lindberg et al., 2016). Second, markedly differences in EFs were seen between the types of stoves used. The EFs of total quantified VOCs for the branches with Heated Kang and semi-gasifier stoves are $1830.0 \pm 330.1$ and $2365.9 \pm 824.7 \mathrm{mg} \mathrm{kg}^{-1}$, respectively. The higher value from semi-gasifier was contributed by more aromatic hydrocarbons generations at relatively higher combustion temperatures (Chen et al., 2016; Lemieux et al., 2004). Even though some studies demonstrated that semi-gasifiers could effectively reduce particulate emission (Martin et al., 2011; Shen et al., 2015; Sun et al., 2017), the raise of VOCs emission is still a concern. Lastly, burning mode 
Atmos. Chem. Phys. Discuss., https://doi.org/10.5194/acp-2018-36

Manuscript under review for journal Atmos. Chem. Phys.

Discussion started: 7 March 2018

(c) Author(s) 2018. CC BY 4.0 License.

(i.e. uses for either heating or cooking) also has strong impacts on EFs. For the heating activities with Heated Kang, users often extend the burning process by shutting down the air supply that leads to an oxygen-deficient environment (Zhuang et al., 2009). The extremely oxygen-deficient condition in Heated Kang favors larger productions of unsaturated alkenes but less alcohol, in comparison with the use of traditional cooking stoves. However, a sufficient air supply may not be a sole solution to reduce VOCs emission. The EFs of non-methane hydrocarbons from wheat straws at open burning are even over $100 \%$ greater than those reported in this study (Lemieux et al., 2004; Li et al., 2009).

\section{Insert Table $1 \&$ Table $S 2$}

Table 2 shows the top ten individual compounds with the highest contributions to the EFs of total quantified VOCs in each test. Acetone, accounted for $10 \%$ of the EFs for the biomass fuels, is one of the dominant VOCs regardless of any stove types and combustion modes. For the emissions from Heated Kang, the fractions of oxygenated-VOCs (O-VOCs) $(27.2-31.2 \%)$ are also much higher than those of other stoves $(6.6-23.1 \%)$. This could be explained by the severe oxygen-deficient condition during straw burning, while the volatile components could not be completely oxidized (Wang et al., 2014). Benzene and toluene are two most abundant aromatic compounds. The sum of their contributions had a descending order of semi-gasifier $>$ cooking stove $>$ Heated Kang. Aromatic hydrocarbons generations are associated with combustion temperatures (Shen et al., 2015). Since the semi-gasifier and traditional cooking stoves had a sufficient air supply, more aromatic hydrocarbons could be favorably formed. Methyl chloride was a sole halogen-containing compound in the top 10 series among the tests. It acts as a typical tracer for straw burning (Liu et al., 2008), and is markedly important in source identification (Wang et al., 2014).

\section{Insert Table 2}

Alkane is the most abundant class for burning of anthracite and honeycomb coals. Dodecane and $n$-butane are the two most dominated alkanes for anthracite $(26.6 \%)$ and honeycomb $(29.2 \%)$ with cooking stoves. With the semi-gasifier, dodecane also accounted for $21.2 \%$ of the total quantified alkanes from the burning of anthracite. Bitumite had a different VOCs emission profile, which is as like as a mix between woody fuels and anthracite coals. Aromatic hydrocarbons (i.e., benzene, toluene and naphthalene) are the top ten species for bitumite with an average contribution of $25.2 \%$, which is similar with loadings of woody fuels with semi-gasifier (Andreae and Merlet, 2001). However, alkanes, including dodecane, n-butane, undecane, iso-butane, propane, iso-pentane and n-pentane, for bitumite burning still had a high contribution of $37.6 \%$ to total quantified VOCs, which is consistent as that for anthracite (Liu et al., 2008). The small variations between the two fuels could be ascribed to their similarities of fuel properties such as ash content and fixed carbon fractions.

\subsection{Source Profiles}

Figure S3 illustrates the source profile for each test in this study. The identity numbers of each VOC are given in Table S1. Among those woody fuels (Fig. S3a), four characteristic fractions are 
shown, including $\mathrm{C}_{3}-\mathrm{C}_{5}$ alkanes, $\mathrm{C}_{3}$ alkene, benzene and toluene, and $\mathrm{C}_{3}-\mathrm{C}_{4}$ carbonyls (i.e., acrolein, acetone and methyl ethyl ketone). Coefficient of divergence (CD) was calculated to measure the similarity of profiles between the tests (Table S3). Similar profiles were obtained with the same stoves $(\mathrm{CD}=0.23$ for Heated Kang, and $\mathrm{CD}=0.35$ for semi-gasifier stove), in comparison of much higher $\mathrm{CD}$ values $(>0.5)$ between different stoves. The main difference between the profiles for Heated Kang and semi-gasifier were aromatic hydrocarbons especially benzene and toluene.

\section{Insert Figure $S 3$}

Insert Table $S 1 \& S 3$

For burning of coal fuels, two more characteristic fractions were ethanol and dichlorobenzene (including three isomers) were seen in their VOC profiles. Moreover, their proportions of halogen containing compounds were obviously higher than those for woody fuels. This phenomenon was also observed in previous studies (Chagger et al., 1999; Liu et al., 2017), attributed to the rich chlorine content in coals (Vassilev et al., 2000; Yudovich and Ketris, 2006). In addition, the woody fuels burning emitted large proportion of alkenes (mainly propylene) while coals combustion emitted more $\mathrm{C}_{11}-\mathrm{C}_{12}$ alkanes (i.e., dodecane and undecane). And dodecane is even the most abundant VOC from the four coals combustion (shown in Table 2). It must be noted that $\mathrm{CD}$ values of bitumite-SG (abbreviated for semi-gasifier) vs. branch-SG/firewood-SG (0.46/0.47) are lower than anthracite-SG vs. branch-SG/firewood-SG (0.58/0.61), indicating VOCs emissions from bitumite are more similar to those of woody fuels than anthracite. The same result was also reported in Wang et al. (2014) in which EFs of VOCs had good correlations with calorific value and volatile matters (VM) of fuels. And in our study, the VM of anthracite, bitumite and firewood were $6.12 \%, 33.20 \%$ and $82.96 \%$ (shown in Table S4), and the calorific values of bitumite and firewood were close as well.

\section{Insert Table S4}

Among the coal fuels, anthracite in coal stove and honeycomb in cook stove showed the highest similarity $(\mathrm{CD}=0.32)$ because the honeycomb briquette used in this study is made of anthracite mixed with some additive. Similar to the woody fuels, coal combustions with semi-gasifier stove favored aromatic hydrocarbon productions. However, semi-gasifier stove emitted less halogen-containing compounds than traditional coal stoves. The differences between combustion styles could affect the distribution of chlorine in solid and vapor phases (Westberg et al., 2003).

For the residue group (Fig.S3c), high CD values for the four characteristic fractions were shown between the woody fuels emission. However, their emissions of halogen-containing compounds were much similar with those for coal fuels because both of biomass residue and coal fuels are rich in chlorine (Baxter, 2005). Table S3 also indicated that more similar VOCs profiles could be obtained with the same types of stove $(\mathrm{CD}=0.52 \& 0.45)$ than the cross-stoves $(\mathrm{CD}=0.71 \sim 0.84)$ even though different solid fuels were used. The VOCs profiles for the traditional cooking stove and semi-gasifier had low CD values $(0.44 \& 0.49)$ as they were both operated at oxygen-rich burning mode. This can be further supported the fact that the VOCs profiles could be affected by both fuel types, stoves and 
Atmos. Chem. Phys. Discuss., https://doi.org/10.5194/acp-2018-36

Manuscript under review for journal Atmos. Chem. Phys.

Discussion started: 7 March 2018

(c) Author(s) 2018. CC BY 4.0 License.

\subsection{Ozone Formation Potentials}

Many VOCs are well known $\mathrm{O}_{3}$ precursors in the atmosphere (Ho et al., 2013; Wang et al., 2017).

To assess the photochemical reactivity of VOCs from the solid fuels burning, two methods were applied to evaluate the contributions of individual VOCs to $\mathrm{O}_{3}$ production. The first one is maximum incremental reactivity (MIR) method (Carter, 2009), which is expressed as:

where $\mathrm{K}_{\mathrm{OH}, \mathrm{i}}$ and $\mathrm{K}_{\mathrm{OH} \text {,propene }}$ are the rate constant of $\mathrm{NMHCs}$ react with $\mathrm{OH}$ at $298 \mathrm{~K}\left(\mathrm{~cm}^{3}\right.$ molecule ${ }^{-1}$ $\left.\mathrm{s}^{-1}\right)$.

The average and standard error values of OFPs and Prop-Equivs are given in Figure 1a and 1b., respectively. The total OFP for solid biomass fuels are higher than those for coal fuels. The highest of total OFP of $5914.8 \mathrm{mg} \mathrm{kg}^{-1}$ was seen for firewood with Heated Kang. Among those burning activities with Heated Kang, alkenes are the major contributors which formed at an oxygen-deficient combustion condition. Higher OFP contributions from aromatic hydrocarbons were seen for the semi-gasifier due to their higher abundances. Alkanes contributed less to the total OFP for most fuels except anthracite due to their relatively low MIR values even though the concentrations of propene and 1,3-butadiene were high (Duan et al., 2008). For the calculated Prop-Equiv (Figure 1b), the contributions from each organic group were similar with the results of OFP. An obvious difference is that alkanes weighted in higher fractions of Prop-Equiv, especially for the cooking and coal fuels emissions. Even though alkanes have relatively high $\mathrm{K}_{\mathrm{OH}}$ values (William P. L. Carter, 2012), their reactivity towards the formation of $\mathrm{O}_{3}$ through photochemical reactions are comparatively less significant. As a result, there might be reasonably over-estimated contributions of alkanes to the $\mathrm{O}_{3}$ formation by Prop-Equiv method.

The total OFP were generally lower for coal burning than biomass burning. The lowest OFP of $50.3 \pm 19.6 \mathrm{mg} \mathrm{kg}^{-1}$ was seen for honeycomb-CS (abbreviated for coal stove). Traditional coal stove, due to its low operation temperature and moderate combustion conditions, has the lowest OFP among the tests, which were two orders of magnitude lower than those for the woody fuels. Aromatic hydrocarbons contributed the majority of total OFP ( $50 \%)$ with the coal stoves. Compared with the biomass fuels, OFP of the non-classified organic group, namely as "others", were much lower for the coal burning, that is consistent with the results obtained in Liu et al. (2008). Bitumite is a mix of high of coal fuels. Besides of fuel features, the semi-gasifier also contributed in the high OFP for 
Atmos. Chem. Phys. Discuss., https://doi.org/10.5194/acp-2018-36

Manuscript under review for journal Atmos. Chem. Phys.

Discussion started: 7 March 2018

(c) Author(s) 2018. CC BY 4.0 License. anthracite-CS $\left(87.5 \pm 3.3 \mathrm{mg} \mathrm{kg}^{-1}\right)$ when anthracite was applied for both fuel tests $(\mathrm{p}<0.05)$. No statistical difference $(p>0.1)$ between OFP for firewood-SG $\left(5743.3 \pm 208.9 \mathrm{mg} \mathrm{kg}^{-1}\right)$ and firewood-HK $\left(5914.8 \pm 1340.5 \mathrm{mg} \mathrm{kg}^{-1}\right)$ was seen, demonstrating that semi-gasifier could not suppress the potential $\mathrm{O}_{3}$ formations in comparison of Heated Kang. Our results could be further concluded that the semi-gasifier stove is not efficient in decreases of both VOCs emissions and OFP even though it showed the feasibility in PM reduction (Shen et al., 2013; Sun et al., 2017).

An evaluation of $\mathrm{O}_{3}$ contribution from solid fuel burning in Guanzhong Basin was conducted and all parameters and results were shown in Table S5. The calculation method was shown in Tie et al. (2015) and Niu et al. (2016). We complicated the box model and atmospheric capacity methods, and applied the hypothesis that the atmosphere would update every $24 \mathrm{~h}$ due to wind speed (Sun et al., 2017; Tie et al., 2015). From Table S5, the emission rate of OFP from biomass fuels $\left(7.17 \times 10^{4} \mathrm{~kg} \mathrm{day}^{-1}\right)$ was $\sim 5$ times higher than that of coal fuels $\left(1.55 \times 10^{4} \mathrm{~kg} \mathrm{day}^{-1}\right)$, provided that the annual consumptions of two types of fuels were in the same level. In addition, based on the calculations, we estimated that the contribution of solid fuel burning to the $\mathrm{O}_{3}$ production in Guanzhong Basin in winter of 2013 was $\sim 20 \%$ (OFP emission rate $/ \mathrm{O}_{3}$ atmospheric capacity). The value was much higher than that estimated with source apportionment approach with $\mathrm{PM}_{2.5}$ of $7.6 \%$ (Huang et al., 2014). Similar phenomenon was seen in other regions of China. For instance, biomass burning contributed $6.7 \%$ to $\mathrm{PM}_{2.5}$ (Huang et al., 2014) but $17.7 \%$ to VOCs (Yuan et al., 2010) in Guangzhou, and for Shanghai, these two fractions were 4.8\% (Huang et al., 2014) and 9.0\% (Cai et al., 2010), respectively. The above discussion could conclude that solid fuel burning contributed more in VOCs emissions than PM productions in atmospheric environment.

As the sample number in this study was limited, using the EFs of VOCs in study to evaluate the regional contribution of $\mathrm{O} 3$ from solid fuel burning could lead to very high uncertainties. However, in our previous study, the box model could output a comparable result when simulating the primary $\mathrm{PM}_{2.5}$ contributions in Guanzhong Plain from solid fuel burning (Sun et al., 2017). Besides, the biggest source of uncertainties in box model was from the fuel consumption. Total solid fuel consumption in this model was evaluated according to relative studies and statistical data from local government. There might be huge gap between our evaluated fuel consumption and the real fuel used. However, the simulated data also had referential meanings to local $\mathrm{O}_{3}$ source identification. Moreover, a detailed activities investigation about solid fuel use in Guanzhong Plain was necessary in future study.

\section{Insert Table S5}

\subsection{Secondary Organic Aerosol Formation Potential}

It has been widely known that VOCs are crucial precursors for secondary organic aerosols (SOA) formation (Ho et al., 2017; Iinuma et al., 2010). The contributions of photochemical reactivity of VOCs from solid fuel burning to SOA formation was thus estimated as well. Firstly, we adopted a Toluene-Equivalent method to calculate the SOA formation potential (SOAP) of VOCs as (Derwent et al., 2010): 


$$
S_{O A P_{i}}=\frac{\text { Increment in SOA mass concentration with species }}{i} \times 100
$$
recognized as an important human-made precursor to SOA formation (Hu et al., 2008; Kleindienst et al., 2007). Secondly, to have a direct evaluation of VOCs to SOA, we converted the Toluene-Equivalent SOAP into mass-based values according to a toluene gas-to-particle chamber test results under a high nitrogen oxide $\left(\mathrm{NO}_{\mathrm{x}}\right)$ condition and low temperature (Johnson et al., 2004). The case was chosen because the simulation conditions were similar with those in Guanzhong Basin in wintertime. Under such conditions, the final gas-to-particle ratio was calculated as 0.045 for toluene (Johnson et al., 2004).

The Toluene-Equivalent SOAPs and the gas-to-particle converted SOAP were shown in Figure 2.

Insert Figure $2 a$ and $2 b$

Overall, aromatic hydrocarbons is the dominated group for the estimated Toluene-Equivalent SOAP due to higher photo-oxidation reactivity than those of alkane and alkenes, especially for the more volatile ones participated in gas-to-particle reactions (Johnson et al., 2004). Followed by aromatic hydrocarbons, alkane was the second largest contributor in Toluene-Equivalent SOAP that could be explained by the relatively high photo-oxidation reactivity for long chain alkanes (Derwent et al., 2010). Since alkenes and oxygenated VOCs (grouped as "Others") are generally inactive in photo-oxidation reactions, their contributions to SOAP were low. Similar observation was seen on the gas-to-particle transferred SOAP (Figure 2b) with lower conversion values.

For biomass fuels, the Toluene-Equivalent SOAPs ranged from $242.6 \pm 32.2$ to $1013.6 \pm 66.6 \mathrm{mg}$ $\mathrm{kg}^{-1}$, with the highest and lowest SOAP found for firewood-SG and branch-TS, respectively. Different from the results of OFP, the SOAP from semi-gasifier emissions were at least double $(\mathrm{p}<0.05)$ of those from Heated Kang when the same fuel was used. Alkane was the second largest contributor with semi-gasifier and cooking stoves but its contribution was lower than alkene with Heated Kang. The SOAPs of the group of "Others" were negligible as they were 1-2 orders of magnitude lower than the major groups $(\mathrm{p}<0.05)$. The average SOAPs were much lower for coal than biomass fuels. The lowest SOAP of $11.0 \pm 4.2 \mathrm{mg} \mathrm{kg}^{-1}$ was observed for honeycomb-CS, and the highest was seen for bitumite-SG of $364.6 \pm 99.2 \mathrm{mg} \cdot \mathrm{kg}^{-1}$, which was even lower than the average value for the biomass burning although the difference was not so significant $(\mathrm{p}>0.05)$. As discussed above, the long chain alkanes and aromatic hydrocarbons are dominated VOCs in the coal burning emissions which occupied the majority of SOAPs. The fractions of alkenes and other group were obviously lower than those of biomass burning $(\mathrm{p}<0.05)$. The mass-based SOAPs ranged from $0.5 \pm 0.2$ to $45.6 \pm 3.0 \mathrm{mg} \mathrm{kg}^{-1}$. Compared with the data in previous studies, the SOAPs were about 1,000 times lower than the EFs of primary $\mathrm{PM}_{2.5}$ (Shen et al., 2015; Sun et al., 2017).

To evaluate the SOA contribution from solid fuel burning in Guanzhong Basin, a rough calculation was done and all parameters and results were shown in Table S6. As shown in Figure S6, the emission rate of SOAP from biomass fuels burning (386.85 $\left.\mathrm{kg} \mathrm{day}^{-1}\right)$ was at the same level as coal burning (410.00 $\left.\mathrm{kg} \mathrm{day}^{-1}\right)$. The contribution of solid fuel burning to SOA in Guanzhong Basin was 
Atmos. Chem. Phys. Discuss., https://doi.org/10.5194/acp-2018-36

Manuscript under review for journal Atmos. Chem. Phys.

Discussion started: 7 March 2018 the primary $\mathrm{PM}_{2.5}$. Hence, the VOCs emission from solid fuel burning was more significantly impacted on the $\mathrm{O}_{3}$ pollution in Guanzhong atmosphere. Uncertainties about SOA contribution evaluation was similar to that in $\mathrm{O}_{3}$ evaluation.

Insert Table S6

\section{Conclusion}

Residential solid fuel burning for cooking and space heating are common in rural Guanzhong Plain,

China. Eight types of widely used solid fuels and three kinds of stoves were selected in this study to detect the VOCs emission profiles and their potentials influence on ozone and SOA formation. VOCs samples were collected on site using a custom-made dilution system set directly on the chimney of each stove. Results of VOCs EFs illustrated that biomass residues burning emitted the highest VOCs with EFs of $1811.4 \pm 833.5-3121.3 \pm 1592.4 \mathrm{mg} \cdot \mathrm{kg}^{-1}$, followed by fuel woods $(1122.2 \pm 178.9-2502.8 \pm 726.4$ $\left.\mathrm{mg} \cdot \mathrm{kg}^{-1}\right)$, and coals $\left(47.2 \pm 19.4-996.8 \pm 476.9 \mathrm{mg} \cdot \mathrm{kg}^{-1}\right)$. Alkanes and aromatic hydrocarbons were the most abundant two categories in VOCs emitted from coal burning. While for residues and fuel woods burning, alkenes and carbonyls also contributed considerable proportions to the total VOCs other than alkanes and aromatic hydrocarbons. Semi-gasifier was proved to be ineffective in decreasing total VOCs emissions for residues and woods burning when compared to traditional stoves, and it even emitted 10 times higher VOCs when using coal as fuels. CD value between VOCs profiles from the same stove was lower than that from different stoves using the same fuel, and this indicated that collecting VOCs profiles by stove types were useful in sources inventory making. Simplified box model results indicated that solid fuel burning related VOCs in Guanzhong plain contributed $\sim 20 \%$ to regional $\mathrm{O}_{3}$ formation, which is much higher than its contribution to SOA formation (only $0.23 \%$ ). Therefore, controlling of VOCs emission from residential solid fuel burning could provide an effective approach to decrease $\mathrm{O}_{3}$ levels in Guanzhong Plain, China.

This research was supported by the National Key Research and Development Plan of China (2017YFC0212205), National Natural Science Foundation of China (41573101), the Natural Science Foundation of Shaanxi Province, China (2016ZDJC-22), a grant from SKLLQG, Chinese Academy of Sciences (SKLLQG1616), and the Fundamental Research Funding for Central Universities in China (xkjc2015002).

\section{Reference}

Adkins, E., Tyler, E., Wang, J., Siriri, D., Modi, V., 2010. Field testing and survey evaluation of household biomass cookstoves in rural sub-Saharan Africa. Energy for Sustainable Development 
14, 172-185.

Akagi, S.K., Yokelson, R.J., Wiedinmyer, C., Alvarado, M.J., Reid, J.S., Karl, T., Crounse, J.D., Wennberg, P.O., 2011. Emission factors for open and domestic biomass burning for use in atmospheric models. Atmospheric Chemistry and Physics 11, 4039-4072.

Andreae, M.O., Artaxo, P., Fischer, H., Freitas, S.R., Gregoire, J.M., Hansel, A., Hoor, P., Kormann, R., Krejci, R., Lange, L., Lelieveld, J., Lindinger, W., Longo, K., Peters, W., de Reus, M., Scheeren, B., Dias, M., Strom, J., van Velthoven, P.F.J., Williams, J., 2001. Transport of biomass burning smoke to the upper troposphere by deep convection in the equatorial region. Geophysical Research Letters 28, 951-954.

Andreae, M.O., Merlet, P., 2001. Emission of trace gases and aerosols from biomass burning. Global Biogeochemical Cycles 15, 955-966.

Atkinson, R., Arey, J., 2003. Atmospheric degradation of volatile organic compounds. Chemical Reviews 103, 4605-4638.

Baxter, L., 2005. Biomass-coal co-combustion: opportunity for affordable renewable energy. Fuel 84, 1295-1302.

Bonjour, S., Adair-Rohani, H., Wolf, J., Bruce, N.G., Mehta, S., Pruess-Ustuen, A., Lahiff, M., Rehfuess, E.A., Mishra, V., Smith, K.R., 2013. Solid Fuel Use for Household Cooking: Country and Regional Estimates for 1980-2010. Environmental Health Perspectives 121, 784-790.

Cai, C., Geng, F., Tie, X., Yu, Q., An, J., 2010. Characteristics and source apportionment of VOCs measured in Shanghai, China. Atmospheric Environment 44, 5005-5014.

Cao, J.J., Wu, F., Chow, J.C., Lee, S.C., Li, Y., Chen, S.W., An, Z.S., Fung, K.K., Watson, J.G., Zhu, C.S., Liu, S.X., 2005. Characterization and source apportionment of atmospheric organic and elemental carbon during fall and winter of 2003 in Xi'an, China. Atmospheric Chemistry and Physics 5, 3127-3137.

Carter, W.P., 2009. Carter W P L. Updated maximum incremental reactivity scale and hydrocarbon bin reactivities for regulatory applications. California Air Resources Board Contract 2009, 339.

Chagger, H.K., Jones, J.M., Pourkashanian, M., Williams, A., Owen, A., Fynes, G., 1999. Emission of volatile organic compounds from coal combustion. Fuel 78, 1527-1538.

Chen, Y., Shen, G., Liu, W., Du, W., Su, S., Duan, Y., Lin, N., Zhuo, S., Wang, X., Xing, B., Tao, S., 2016. Field measurement and estimate of gaseous and particle pollutant emissions from cooking and space heating processes in rural households, northern China. Atmospheric Environment 125, 265-271.

Derwent, R.G., Jenkin, M.E., Utembe, S.R., Shallcross, D.E., Murrells, T.P., Passant, N.R., 2010. Secondary organic aerosol formation from a large number of reactive man-made organic compounds. Science of the Total Environment 408, 3374-3381.

Duan, J., Tan, J., Yang, L., Wu, S., Hao, J., 2008. Concentration, sources and ozone formation potential of volatile organic compounds (VOCs) during ozone episode in Beijing. Atmospheric Research 88, 25-35.

Ho, K.F., Ho, S.S.H., Lee, S.C., Louie, P.K.K., Cao, J., Deng, W., 2013. Volatile Organic Compounds in Roadside Environment of Hong Kong. Aerosol and Air Quality Research 13, 1331-1347.

Ho, S.S.H., Chow, J.C., Watson, J.G., Wang, L., Qu, L., Dai, W., Huang, Y., Cao, J., 2017. Influences of relative humidities and temperatures on the collection of C-2-C-5 aliphatic hydrocarbons with multi-bed (Tenax TA, Carbograph 1TD, Carboxen 1003) sorbent tube method. Atmospheric Environment 151, 45-51.

Hou, B.-D., Tang, X., Ma, C., Liu, L., Wei, Y.-M., Liao, H., 2017. Cooking fuel choice in rural China: results from microdata. Journal of Cleaner Production 142, 538-547.

Hu, D., Bian, Q., Li, T.W.Y., Lau, A.K.H., Yu, J.Z., 2008. Contributions of isoprene, monoterpenes, beta-caryophyllene, and toluene to secondary organic aerosols in Hong Kong during the summer of 2006. Journal of Geophysical Research-Atmospheres 113.

Huang, R.-J., Zhang, Y., Bozzetti, C., Ho, K.-F., Cao, J.-J., Han, Y., Daellenbach, K.R., Slowik, J.G., Platt, S.M., Canonaco, F., Zotter, P., Wolf, R., Pieber, S.M., Bruns, E.A., Crippa, M., Ciarelli, G., Piazzalunga, A., Schwikowski, M., Abbaszade, G., Schnelle-Kreis, J., Zimmermann, R., An, Z., Szidat, S., Baltensperger, U., El Haddad, I., Prevot, A.S.H., 2014. High secondary aerosol contribution to particulate pollution during haze events in China. Nature 514, 218-222.

Iinuma, Y., Boege, O., Graefe, R., Herrmann, H., 2010. Methyl-Nitrocatechols: Atmospheric Tracer Compounds for Biomass Burning Secondary Organic Aerosols. Environmental Science \& Technology 44, 8453-8459.

Johnson, D., Jenkin, M.E., Wirtz, K., Martin-Reviejo, M., 2004. Simulating the Formation of Secondary Organic Aerosol from the Photooxidation of Toluene. Environmental Chemistry 1, $150-165$. 
Kleindienst, T.E., Jaoui, M., Lewandowski, M., Offenberg, J.H., Lewis, C.W., Bhave, P.V., Edney, E.O., 2007. Estimates of the contributions of biogenic and anthropogenic hydrocarbons to secondary organic aerosol at a southeastern US location. Atmospheric Environment 41, 8288-8300.

Langmann, B., Duncan, B., Textor, C., Trentmann, J., van der Werf, G.R., 2009. Vegetation fire emissions and their impact on air pollution and climate. Atmospheric Environment 43, 107-116.

Lee, S., Baumann, K., Schauer, J.J., Sheesley, R.J., Naeher, L.P., Meinardi, S., Blake, D.R., Edgerton, E.S., Russell, A.G., Clements, M., 2005. Gaseous and particulate emissions from prescribed burning in Georgia. Environmental Science \& Technology 39, 9049-9056.

Lei, Y., Zhang, Q., He, K.B., Streets, D.G., 2011. Primary anthropogenic aerosol emission trends for China, 1990-2005. Atmospheric Chemistry and Physics 11, 931-954.

Lemieux, P.M., Lutes, C.C., Santoianni, D.A., 2004. Emissions of organic air toxics from open burning: a comprehensive review. Progress in Energy and Combustion Science 30, 1-32.

Li, X., Wang, S., Duan, L., Hao, J., 2009. Characterization of non-methane hydrocarbons emitted from open burning of wheat straw and corn stover in China. Environmental Research Letters 4.

Lindberg, D., Niemi, J., Engblom, M., Yrjas, P., Lauren, T., Hupa, M., 2016. Effect of temperature gradient on composition and morphology of synthetic chlorine-containing biomass boiler deposits. Fuel Processing Technology 141, 285-298.

Liu, C., Zhang, C., Mu, Y., Liu, J., Zhang, Y., 2017. Emission of volatile organic compounds from domestic coal stove with the actual alternation of flaming and smoldering combustion processes. Environmental Pollution 221, 385-391.

Liu, Y., Shao, M., Fu, L., Lu, S., Zeng, L., Tang, D., 2008. Source profiles of volatile organic compounds (VOCs) measured in China: Part I. Atmospheric Environment 42, 6247-6260.

Martin, W.J., II, Glass, R.I., Balbus, J.M., Collins, F.S., 2011. A Major Environmental Cause of Death. Science 334, 180-181.

Niu, X., Cao, J., Shen, Z., Ho, S.S.H., Tie, X., Zhao, S., Xu, H., Zhang, B., Huang, R., 2016. PM2.5 from the Guanzhong Plain: Chemical composition and implications for emission reductions. Atmospheric Environment 147, 458-469.

Reid, J.S., Koppmann, R., Eck, T.F., Eleuterio, D.P., 2005. A review of biomass burning emissions part II: intensive physical properties of biomass burning particles. Atmospheric Chemistry and Physics $5,799-825$.

Shen, G., Chen, Y., Xue, C., Lin, N., Huang, Y., Shen, H., Wang, Y., Li, T., Zhang, Y., Su, S., Huangfu, Y., Zhang, W., Chen, X., Liu, G., Liu, W., Wang, X., Wong, M.-H., Tao, S., 2015. Pollutant Emissions from Improved Coal- and Wood-Fuelled Cookstoves in Rural Households. Environmental Science \& Technology 49, 6590-6598.

Shen, G., Tao, S., Chen, Y., Zhang, Y., Wei, S., Xue, M., Wang, B., Wang, R., Lu, Y., Li, W., Shen, H., Huang, Y., Chen, H., 2013. Emission Characteristics for Polycyclic Aromatic Hydrocarbons from Solid Fuels Burned in Domestic Stoves in Rural China. Environmental Science \& Technology 47, 14485-14494.

Shen, Z., Cao, J., Arimoto, R., Han, Z., Zhang, R., Han, Y., Liu, S., Okuda, T., Nakao, S., Tanaka, S., 2009. Ionic composition of TSP and PM2.5 during dust storms and air pollution episodes at Xi'an, China. Atmospheric Environment 43, 2911-2918.

Sun, J., Shen, Z., Cao, J., Zhang, L., Wu, T., Zhang, Q., Yin, X., Lei, Y., Huang, Y., Huang, R.J., Liu, S., Han, Y., Xu, H., Zheng, C., Liu, P., 2017. Particulate matters emitted from maize straw burning for winter heating in rural areas in Guanzhong Plain, China: Current emission and future reduction. Atmospheric Research 184, 66-76.

Tie, X., Zhang, Q., He, H., Cao, J., Han, S., Gao, Y., Li, X., Jia, X.C., 2015. A budget analysis of the formation of haze in Beijing. Atmospheric Environment 100, 25-36.

Vassilev, S.V., Eskenazy, G.M., Vassileva, C.G., 2000. Contents, modes of occurrence and origin of chlorine and bromine in coal. Fuel 79, 903-921.

Wang, H., Lou, S., Huang, C., Qiao, L., Tang, X., Chen, C., Zeng, L., Wang, Q., Zhou, M., Lu, S., Yu, X., 2014. Source Profiles of Volatile Organic Compounds from Biomass Burning in Yangtze River Delta, China. Aerosol and Air Quality Research 14, 818-828.

Wang, T., Xue, L., Brimblecombe, P., Lam, Y.F., Li, L., Zhang, L., 2017. Ozone pollution in China: A review of concentrations, meteorological influences, chemical precursors, and effects. Science of the Total Environment 575, 1582-1596.

Westberg, H.M., Bystrom, M., Leckner, B., 2003. Distribution of potassium, chlorine, and sulfur between solid and vapor phases during combustion of wood chips and coal. Energy \& Fuels 17, 18-28.

William P. L. Carter, G.H., David R. Cocker III, and Shunsuke Nakao, 2012. SOA Formation: Chamber Study and Model Development[J]. California Air Resources Board 2012, 326. 
Atmos. Chem. Phys. Discuss., https://doi.org/10.5194/acp-2018-36

Manuscript under review for journal Atmos. Chem. Phys.

Discussion started: 7 March 2018

(c) Author(s) 2018. CC BY 4.0 License.

516 Winijkul, E., Bond, T.C., 2016. Emissions from residential combustion considering end-uses and spatial constraints: Part II, emission reduction scenarios. Atmospheric Environment 124, 1-11.

Yuan, B., Liu, Y., Shao, M., Lu, S., Streets, D.G., 2010. Biomass Burning Contributions to Ambient VOCs Species at a Receptor Site in the Pearl River Delta (PRD), China. Environmental Science \& Technology 44, 4577-4582.

Yudovich, Y.E., Ketris, M.P., 2006. Chlorine in coal: A review. International Journal of Coal Geology $67,127-144$.

Zhang, J.J., Smith, K.R., 2007. Household air pollution from coal and biomass fuels in China: Measurements, health impacts, and interventions. Environmental Health Perspectives 115, 848-855.

Zhang, Q., Shen, Z., Cao, J., Zhang, R., Zhang, L., Huang, R.J., Zheng, C., Wang, L., Liu, S., Xu, H., Zheng, C., Liu, P., 2015. Variations in PM2.5, TSP, BC, and trace gases (NO2, SO2, and O-3) between haze and non-haze episodes in winter over Xi'an, China. Atmospheric Environment 112, 64-71.

Zhuang, Z., Li, Y., Chen, B., Guo, J., 2009. Chinese kang as a domestic heating system in rural northern China-A review. Energy and Buildings 41, 111-119. 
Atmos. Chem. Phys. Discuss., https://doi.org/10.5194/acp-2018-36

Manuscript under review for journal Atmos. Chem. Phys.

Discussion started: 7 March 2018

(c) Author(s) 2018. CC BY 4.0 License.

(c) (1)

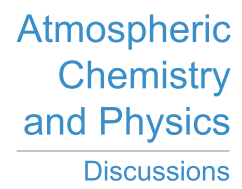

533 Figure Legends

534 Figure 1 EFs of MIR-OFP (a) and propane-equivalent (b) emitted from residential heating and cooking 535 activities

536 Figure 2 EFs of SOAP (Toluene-equivalent) (a) and SOAP (Gas to Particle transfer rate) (b) emitted

537 from residential heating and cooking activities

538

539 Supporting Information (SI)

540 (1) SI1: Raw data of manuscript. (2) SI2: Detailed information on results and discussions: Table S1-S6

541 and Figure S1-S3.

542 
Atmos. Chem. Phys. Discuss., https://doi.org/10.5194/acp-2018-36

Manuscript under review for journal Atmos. Chem. Phys.

Discussion started: 7 March 2018

(c) Author(s) 2018. CC BY 4.0 License.
Atmospheric

Chemistry and Physics

Discussions

\section{(c) (i)}

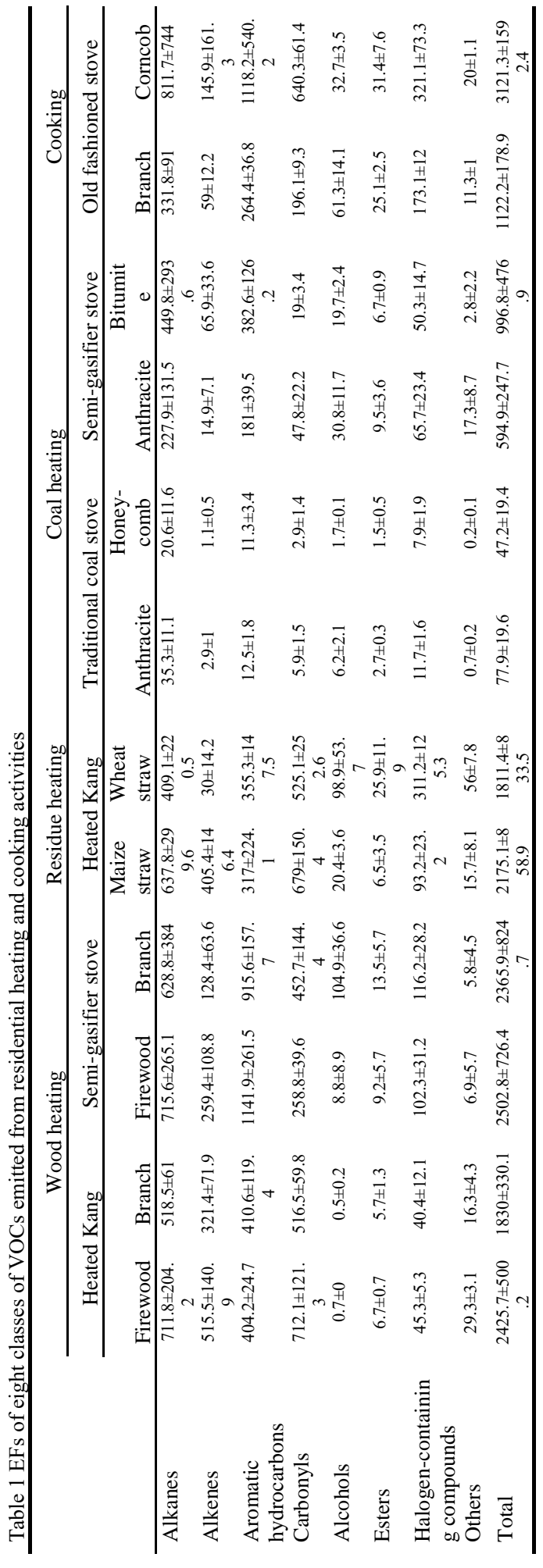


Atmos. Chem. Phys. Discuss., https://doi.org/10.5194/acp-2018-36

Manuscript under review for journal Atmos. Chem. Phys.

Discussion started: 7 March 2018

(c) Author(s) 2018. CC BY 4.0 License.
Atmospheric

Chemistry

and Physics

Discussions

\section{(c) (i)}
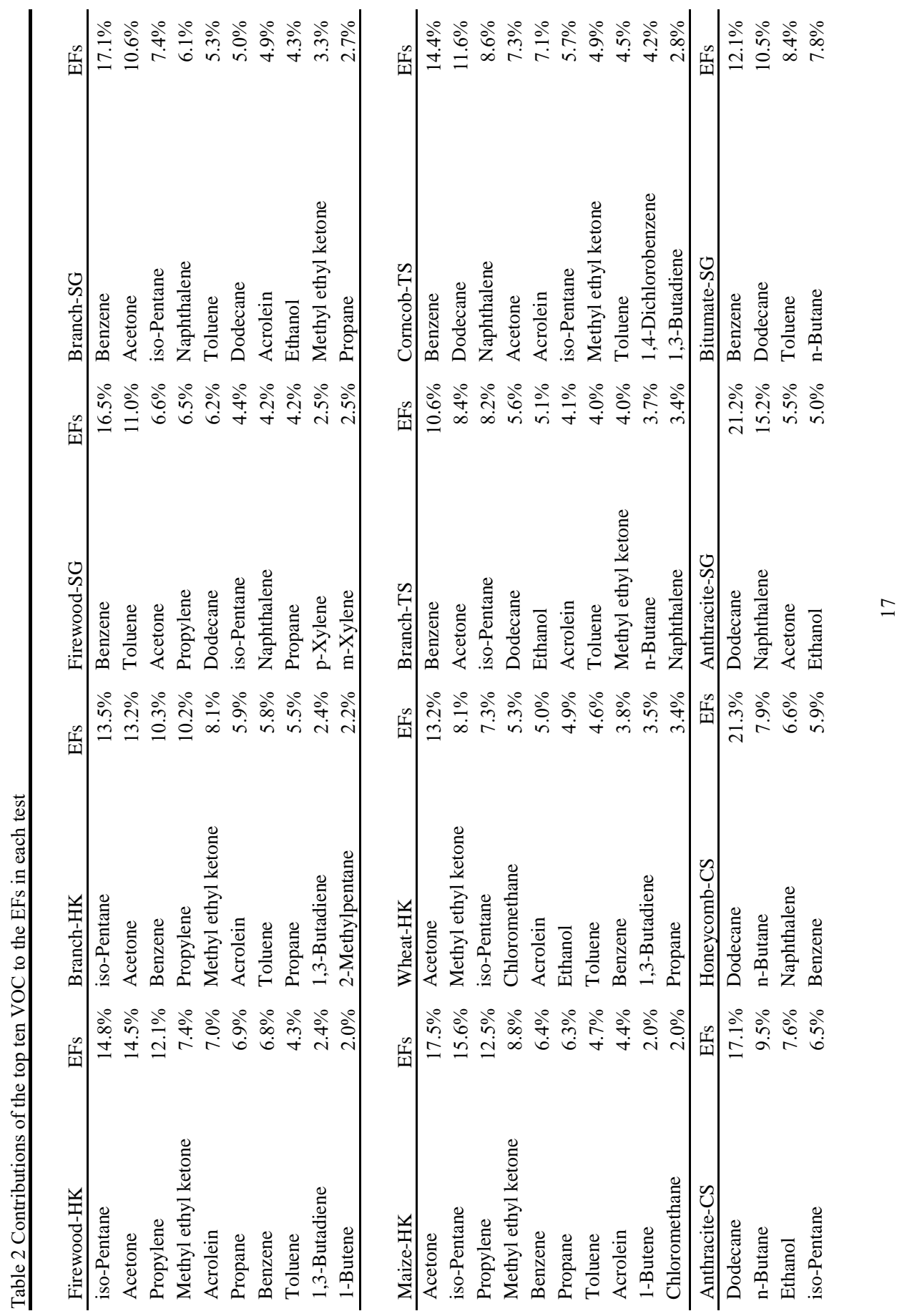
Atmos. Chem. Phys. Discuss., https://doi.org/10.5194/acp-2018-36

Manuscript under review for journal Atmos. Chem. Phys.

Discussion started: 7 March 2018

(C) Author(s) 2018. CC BY 4.0 License.

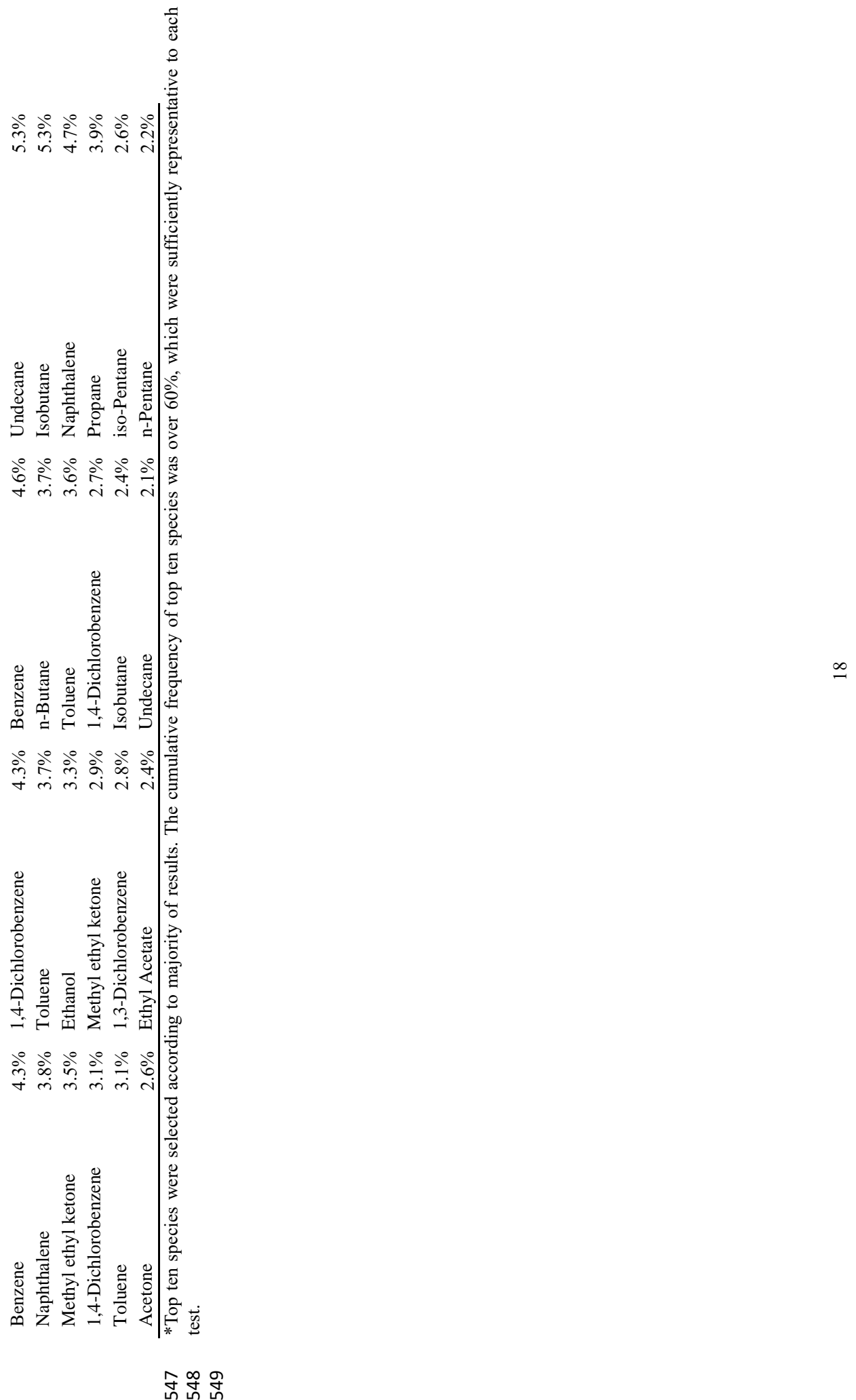


Atmos. Chem. Phys. Discuss., https://doi.org/10.5194/acp-2018-36

Manuscript under review for journal Atmos. Chem. Phys.

Discussion started: 7 March 2018

(c) Author(s) 2018. CC BY 4.0 License.
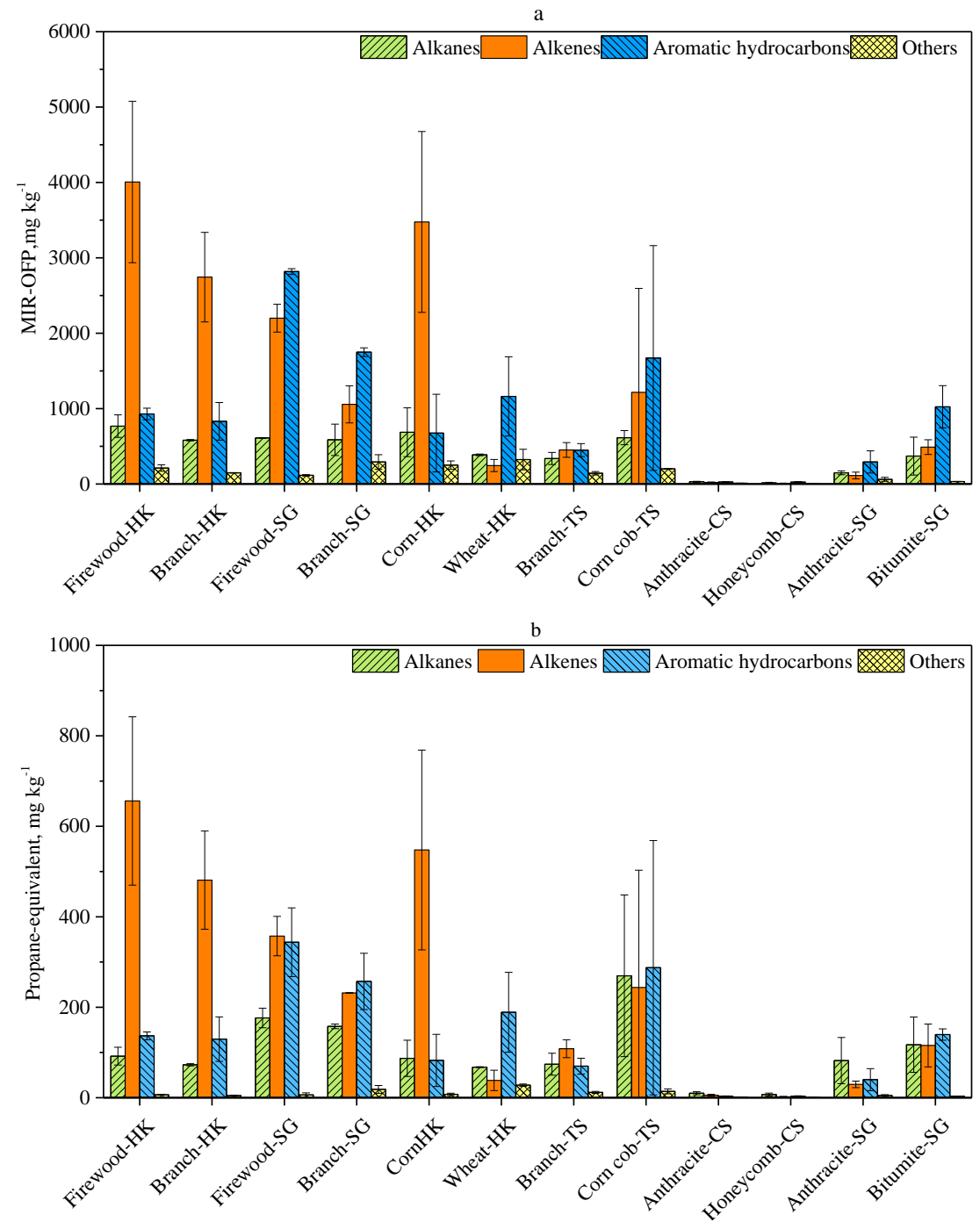

Figure 1. EFs of MIR-OFP (a) and propane-equivalent (b) emitted from residential heating and cooking activities 
Atmos. Chem. Phys. Discuss., https://doi.org/10.5194/acp-2018-36

Manuscript under review for journal Atmos. Chem. Phys.

Discussion started: 7 March 2018

(c) Author(s) 2018. CC BY 4.0 License.

\section{(c) (1)}
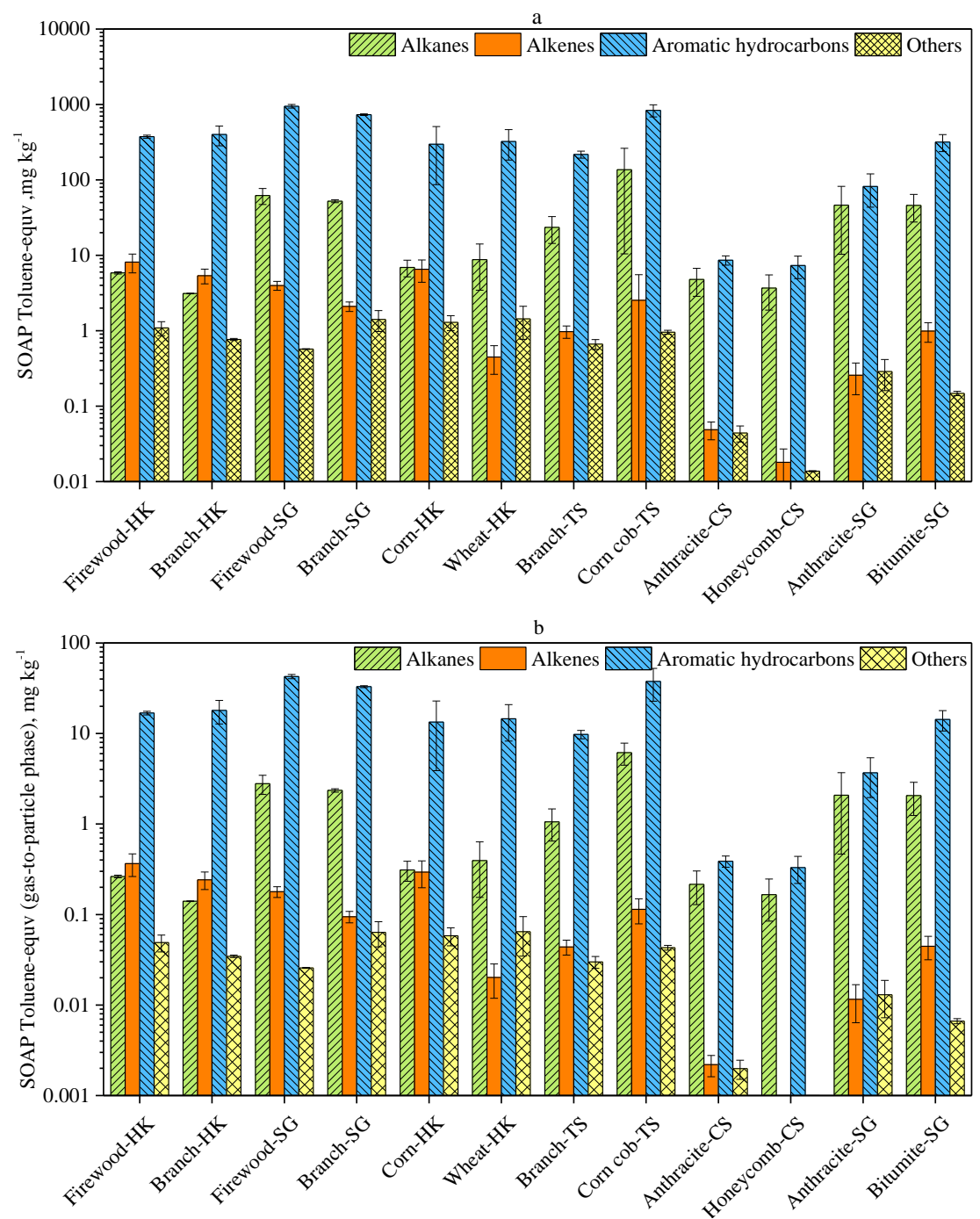

Figure 2 EFs of SOAP (Toluene-equivalent) (a) and SOAP (Gas to Particle transfer rate) (b) emitted from residential heating and cooking activities 